\title{
戸建住宅 8 棟の熱損失係数に関する同時測定と設計值との比較 SIMULTANEOUS MEASUREMENT ON HEAT LOSS COEFFICIENT OF EIGHT DETACHED HOUSES AND COMPARISON WITH DESIGN VALUE
}

\author{
吉野 博*, 長友宗重**, 石川善美***, 松本真一**** \\ Hiroshi YOSHINO, Muneshige NAGATOMO, Yoshimi ISHIKAWA \\ and Shin-ichi MATSUMOTO
}

\begin{abstract}
This paper describes the results of the field measurement using eight detached houses in the same site in Sendai City to investigate the airtightness and the heat loss coefficient. The heat loss coefficient of each house was measured simultaneously according to the measurement method of JS's report, and was compared with the design. value. The major results are as follows :

(1) The equivalent air leakage area per floor area of these houses was $3.0 \sim 16.4 \mathrm{~cm}^{2} / \mathrm{m}^{2}$. The house with the largest leakage area was constructed by conventional method.

(2) The heat loss coefficient per floor area was $1.74 \sim 3.08 \mathrm{kcal} / \mathrm{m}^{2} \mathrm{~h}^{\circ} \mathrm{C}$. But this value depended on the climatic condition and measurement condition.

(3) Measured value of heat loss coefficient except infiltration load using the data of airtightness was within about $\pm 15 \%$ of the design value using specifications.
\end{abstract}

Keywords: heat loss coefficient, airtightness, heat load of infiltration, field measurement 熱損失係数, 気密性能, 換気負荷, 現場実測

\section{1. 序}

住宅の熱損失係数は，設計図書における壁体構成に基 づいて，計算によって算出することができる。これはい わば所期の性能である。一方，完成された住宅は必ずし も設計通りに施工されているとは限らず，また施工の精 度にもばらつきがあるため, 所期の性能か確保されてい るかどうかは不明である。そこで今回，隣接して建設さ れた8棟の建て売り住宅を対象に，所期の熱性能に対し て，実際はどの程度ばらつくものなのかを明らかにする ことを主目的として，日本工業規格(案)「現場における 部屋の暖房用熱損失係数測定方法」 ${ }^{2)} に$ 従い, 熱損失係数

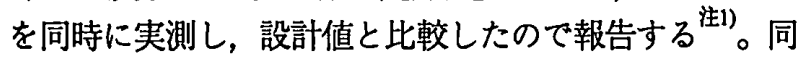
時測定を行えば，外界条件の違いによる測定結果の誤差 を取り除いた住戸間の比較が可能となる。ただし，今回 は，実測に必要な暖房用電気容量が住戸によって不十分 であったため，8棟を数棟づつ2回に分けて測定すること とした。その際，1棟のみは2回とも実測し，同一の住宅
において，条件の異なる2回の測定結果にどの程度の差が 生じるかについても調べることとした。この方法にした がって熱損失俰数を求めた場合, 異なる気象条件の下で は異なった值を示すことが, 熱容量の大きいパッシブ ソーラーシステム試験家屋を対象とした実測 ${ }^{33,4)}$ から，筆 者らは明らかにしており，今回の実測は，熱容量の小さ い住宅の場合について，どのような結果が得られるかに ついて調べるものである。測定は，住宅竣工直後の1990 年4月に行った。

\section{2. 対象住戸}

実測対象は，仙台市北部の新興住宅地に建つ8住戸 (No.1 8)である。これらは，それぞれ，異なる住宅メー カー, 工務店による建て売り住宅として，連続した敷地 内に建てられ，1990年3月に竣工した。図1に，配置図を 示す。8棟はすべて南を向いており，敷地は平坦で，南側
* 東北大学工学部建築学科 教授. 工博

** 鹿島建設俳 尃務・工博

*** 東北工業大学工業意匠学科 教授・工博

**** 東北大学工学部建築学科 講師 ·博士 (工学)
Prof., Dept. of Architecture, Faculty of Engineering, Tohoku Univ., Dr. Eng.

Senior Managing Director, Kajima Corp., Dr. Eng.

Prof., Dept. of Industrial Design, Tohoku Institute of Technology, Dr. Eng.

Lecturer, Dept. of Architecture, Faculty of Engineering, Tohoku Univ., Dr. Eng. 


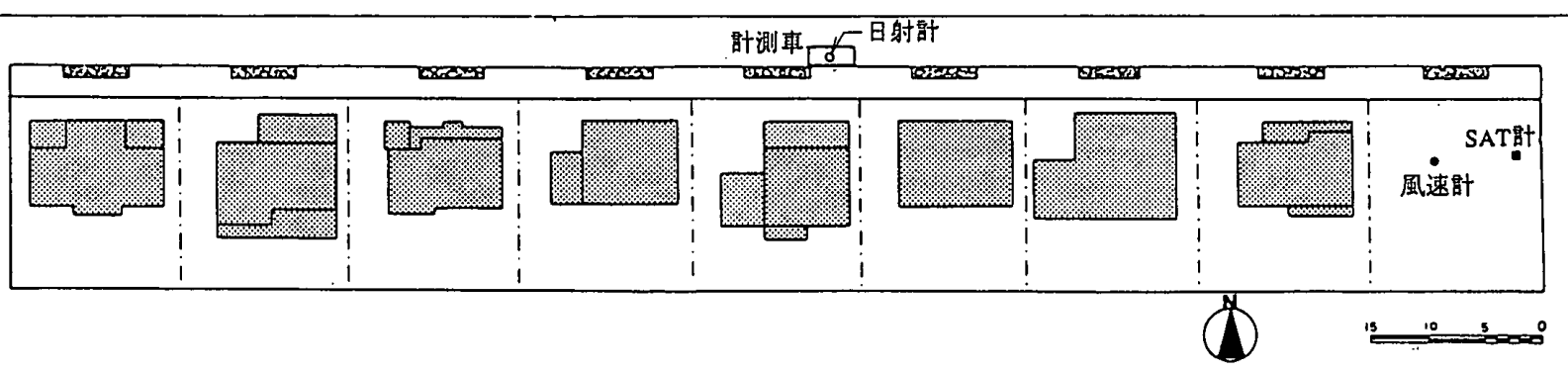

図1 対象住戸の配置図

表1 対象住戸の断熱仕様

\begin{tabular}{|c|c|c|c|c|c|c|c|c|c|}
\hline \multicolumn{2}{|c|}{ 住戸No. } & 1 & 2 & 3 & 4 & 5 & 6 & 7 & 8 \\
\hline \multicolumn{2}{|c|}{ 工法 } & $\begin{array}{c}\text { 木質軸組 } \\
\text { (在来) }\end{array}$ & $2 \times 4$ & 軽量鉄骨 & 軽鉄パネル & 木質パネル & ラー铁筋 & $\begin{array}{c}2 \times 4 \\
\text { ユニット }\end{array}$ & 軽量铁骨 \\
\hline \multirow{3}{*}{$\begin{array}{c}\text { 断熱材 } \\
\text { 厚さ } \\
\text { [mm] }\end{array}$} & 床 & 50 & 35 & 30 & $30+45$ & 75 & 45 & 100 & 50 \\
\hline & 外壁 & 50 & 100 & 75 & 55 & 75 & 65 & 100 & 100 \\
\hline & 天井 & 100 & 50 & 100 & 100 & 50 & 100 & 100 & 75 \\
\hline \multicolumn{2}{|c|}{ 空ガラス搆成 } & 一重 & 一部椱層 & 一重 & 一重 & 一部複層 & 一重 & 一部二重 & 一重 \\
\hline \multicolumn{2}{|c|}{ 延床面栍 $\left[\mathrm{m}^{2}\right]$} & 128 & 129 & 129 & 129 & 130 & 125 & 126 & 130 \\
\hline \multicolumn{2}{|c|}{$\begin{array}{l}\text { 熟損失保数* } \\
{\left[\mathrm{kcal} / \mathrm{m}^{2} \mathrm{~h}{ }^{2} \mathrm{C}\right]}\end{array}$} & 2.33 & 1.68 & 2.1 & 2.49 & 2.02 & 1.95 & 1.46 & 2.22 \\
\hline
\end{tabular}

*設計図春より求めた值(壁体からの貫流熱損失のみ)

からの日射を遮るものはない。表1は，各住戸の断熱仕様 などを示したものである。住戸はすべて2階建てで, No.3 とNo.8の住戸が軽量鉄骨プレファプ工法であるほかは， それぞれ異なる工法で作られている。延床面積は， $125-130 \mathrm{~m}^{2}$ と同規模である。断熱材はいずれの住戸も外 壁，床，天井すべてに施されているが，その材料と厚さ は住戸によって異なる。空の構成は，No.2，5，7の住戸 の一部がサッシ二重または複層ガラスであるが，その他 は単層ガラスで, すべてアルミサッシである。ただし， 和室は，いずれの住戸においても単層ガラスに障子が組 み合わされている。

設計図書の壁体構成より見積もった熱損失係数 ${ }^{\text {浪2) }(い わ ~}$ ゆる総括熱貫流率で，換気の分は含まない)は，床面積あ たり， 1.46(No.7) - $2.49 \mathrm{kcal} / \mathrm{m}^{2} \mathrm{~h}^{\circ} \mathrm{C}(\mathrm{No} .4)$ の範囲に分布してい る。ただしこの熱損失係数の算定に際しては，1980年 2月に告示された「住宅に係るエネルギーの使用の合理化 に関する建築主の判断の基準」（旧省エネルギー基準)の 熱損失係数の算定方法に則り，床の熱貫流率は，係数 0.6 を乗じた值とした。

また，参考までに，これら8住戸を含めて，当時，東北 地方に建設される住宅の断熱性能がどの程度の水準であ るかを知るために，仙台市の住宅建設会社に対して標準 仕様に関するアンケート調査を行った。調査の時期は 1990年10月 1991年6月，回答数は25件である。表2に，各 部位の壁体構成から算出される熱貫流率を，測定対象住 戸を含めて比較した結果を示す。各部位において，8住戸
表2 熱貫流率に関する対象住戸とアンケート結果の比較

\begin{tabular}{|c|c|c|c|c|c|c|}
\hline \multirow{2}{*}{$\begin{array}{c}\text { 熱貫流率 } \\
{\left[\mathrm{kcal} / \mathrm{m}^{2} \mathrm{~h}^{2} \mathrm{C}\right]}\end{array}$} & \multicolumn{2}{|c|}{ 外壁 } & \multicolumn{2}{|c|}{ 床 } & \multicolumn{2}{|c|}{ 天井 } \\
\hline & A & $\mathrm{B}$ & A & $\mathrm{B}$ & $\mathrm{A}$ & B \\
\hline$\sim 0.3$ & 1 & 1 & 1 & & & \\
\hline $0.3 \sim 0.4$ & 8 & 2 & 2 & 1 & 1 & \\
\hline $0.4 \sim 0.5$ & 7 & 3 & & 1 & 18 & 4 \\
\hline $0.5 \sim 0.6$ & 6 & 2 & 7 & 2 & 1 & 1 \\
\hline $0.6 \sim 0.7$ & 3 & & 3 & 1 & 4 & 3 \\
\hline $0.7 \sim 0.8$ & & & 3 & 2 & 1 & \\
\hline $0.8 \sim 0.9$ & & & 6 & 1 & & \\
\hline $0.9 \sim 1.0$ & & & & & & \\
\hline 1.0 & & & 3 & & & \\
\hline 旧省エネ基準 & \multicolumn{2}{|c|}{0.7} & \multicolumn{2}{|c|}{0.7} & \multicolumn{2}{|c|}{0.6} \\
\hline 新省エネ基準 & \multicolumn{2}{|c|}{0.66} & \multicolumn{2}{|c|}{0.55} & \multicolumn{2}{|c|}{0.44} \\
\hline
\end{tabular}

の分布はアンケート調査結果の範囲内にあることがわか る。すなわち, 今回測定の対象となった8住戸は, 調査時 期当時の標準的な仕様を用いた住戸であると言える。な お，宮城県の属する地域の省エネルギー基準值 ${ }^{(6)}$ 併せて 示したが，外壁と天井については，ほとんどすべての住 戸及び標準仕様で旧基準值を上回っている。しかし，床 については，調査した標準仕様で数件，実測对象住戸の うち3戸が旧基準值を下回っている。アンケート調查結果 によれば，床の断熱材は，厚さ $30 \mathrm{~mm}$ 前後のものが多く， 他の部位に比べると若干軽視されているようである。 


\section{3. 気密性能の測定}

\section{1 測定の方法}

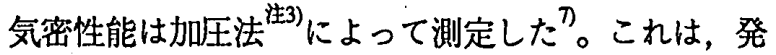
泡ポリスチレン板をはめ込んだ居間または和室の空にダ クトを貫通させ，室内側のダクト先端に送風機を接続し て住戸内に空気を送り込み，そのときの室内外圧力差と 通気量の関係から覙間量を推定するものである。

\section{2 測定結果}

各住戸とも台所, 浴室, 便所の換気扇をシールした場 合とシールしない場合の二通りについて測定した。図2 に,シールした場合の湘定結果を示す。また，これらの 湘定結果から，隙間の相当開口面積 $\alpha \mathrm{A}$ ，及び，延末面積 $\mathrm{S}$ 当たりの隐間の相当開口面積 $\alpha \mathrm{A} / \mathrm{S}$ を求めた結果を表 $3 に$ 示す。

換気扇をシールしない場合， $\alpha \mathrm{A} / \mathrm{S}$ は，No.1の住戸が $16.4 \mathrm{~cm}^{2} / \mathrm{m}^{2}$ と最も大きく, No.2の住戸が $3 \mathrm{~cm}^{2} / \mathrm{m}^{2}$ と最も小 さい。この2つの住戸を除くと，残りは，概ね $25 \sim 7 \mathrm{~cm}^{2} / \mathrm{m}^{2}$

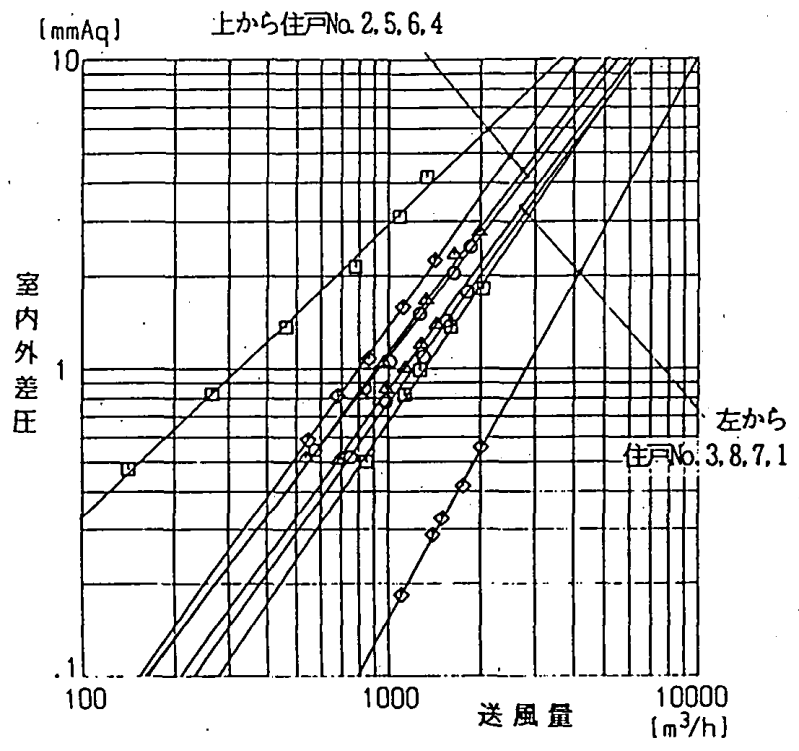

図2 気密性能の測定結果

表3 隙間の相当開口面積の算定結果

\begin{tabular}{|c|c|c|c|c|c|c|c|c|c|c|}
\hline \multirow{2}{*}{$\begin{array}{l}\text { 住戸 } \\
\text { No. }\end{array}$} & \multicolumn{4}{|c|}{ シールをしない㘯合 } & \multicolumn{4}{|c|}{ 換気厥をシールした場合 } & \multirow{2}{*}{$\begin{array}{c}\text { 換気扇部 } \\
\text { 分の陁間 } \\
{\left[\mathrm{cm}^{2}\right]}\end{array}$} & \multirow{2}{*}{$\begin{array}{c}\text { 換気扇部 } \\
\text { 分の陕間 } \\
\text { の割合 } \\
{[\%]} \\
\end{array}$} \\
\hline & $\mathrm{n}$ & $\begin{array}{c}Q_{0} \\
{\left[\mathrm{~m}^{3} / \mathrm{h}\right]}\end{array}$ & $\begin{array}{c}\alpha A \\
{\left[\mathrm{~cm}^{2}\right]}\end{array}$ & $\begin{array}{c}\alpha \mathrm{A} / \mathrm{S} \\
{\left[\mathrm{cm}^{2} / \mathrm{m}^{2}\right]}\end{array}$ & $\mathbf{n}$ & $\begin{array}{c}\mathrm{Q}_{0} \\
{\left[\mathrm{~m}^{3} / \mathrm{h}\right]}\end{array}$ & $\begin{array}{c}\alpha A \\
{\left[\mathrm{~cm}^{2}\right]}\end{array}$ & $\begin{array}{c}\dot{\alpha} \mathrm{A} / \mathrm{S} \\
{\left[\mathrm{cm}^{2} / \mathrm{m}^{2}\right]}\end{array}$ & & \\
\hline 1 & 1.7 & 3021.5 & 2084.8 & 16.35 & 1.8 & 2757.4 & 1902.6 & 14.92 & 182.2 & 8.7 \\
\hline 2 & 1.3 & 564.6 & 386.6 & 3.02 & 0.9 & 317.6 & 219.1 & 1.7 & 167.5 & 43.3 \\
\hline 3 & 1.4 & 1211.4 & 835.9 & 6.5 & 1.4 & 1107.3 & 764 & 5.94 & 71.9 & 8.6 \\
\hline 4 & 1.4 & 992.8 & 685 & 5.29 & 1.3 & 923.9 & 637.5 & 4.93 & 47.5 & 6.9 \\
\hline 5 & 1.5 & 918.4 & 633.7 & 4.89 & 1.4 & 786.5 & 542.7 & 4.19 & 91 & 14.3 \\
\hline 6 & 1.3 & 994.5 & 686.2 & 5.47 & 1.3 & 895.9 & 618.9 & 4.94 & 67.3 & 9.8 \\
\hline 7 & 1.4 & 1345.2 & 928.2 & 7.36 & 1.5 & 1298.4 & 895.9 & 7.1 & 32.3 & 3.5 \\
\hline 8 & 1.3 & 1310.8 & 904.5 & 6.96 & 1.4 & 1185.3 & 817.9 & 6.29 & 86.6 & 9.6 \\
\hline
\end{tabular}

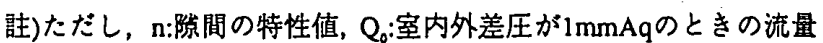
$\alpha A$ :隐間の相当開口面積， $s:$ 延床面積

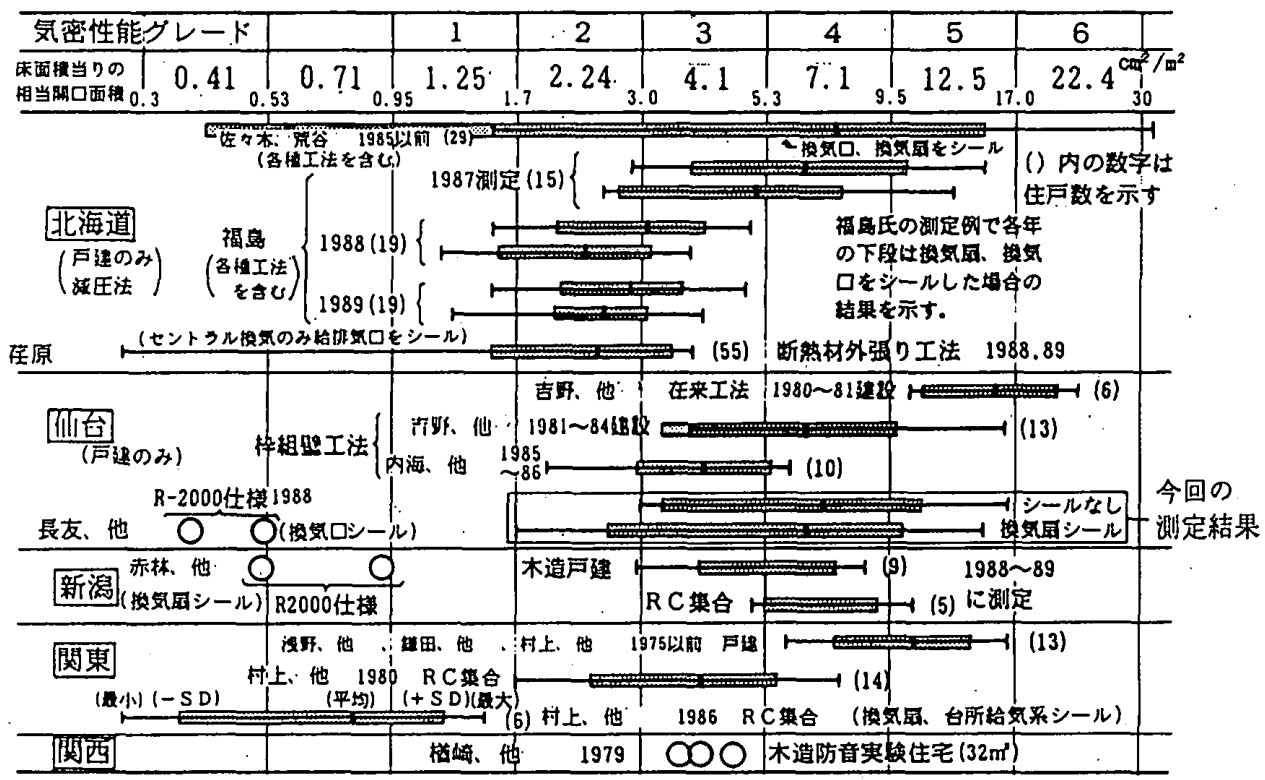

図3気密性能のグレード 
であるから，No.1の住戸だけ，他よりも特に大きな值と なっていることが判る。No.1は在来术造軸組工法, No.2 はツーバイフォーの枠組壁工法の住戸である。また，換 気扇をシールした場合とシールしない場合の測定結果か ら，換気扇部分の隙間量を見積もると， $32 \sim 182 \mathrm{~cm}^{2} / \mathrm{m}^{2} に$ 分布している。No.1の住戸の換気扇部分の隙間量は $182 \mathrm{~cm}^{2}$ と最も大きく，全体の隙間量の約 $9 \%$ を占める。次 いでNo.2の住戸が167 $\mathrm{cm}^{2}$ と大きいが，この住戸の場合 は，気密性能が高いため，換気扇の覙間が住戸全体の淂 間量の $43 \%$ と約半分を占める。

以上の結果を過去の測定結果” $と$ 比較すると, 四3のよ うになる。これによれば，今回測定した住宅の気密性能 は，換気扇のシールをした場合，グレード2 5, シールを しない場合,グレード3 5に分布している。

\section{4. 熱損失係数の測定}

\section{1 測定方法}

日本工業規格案「現場における部屋の暖房用熱損失係 数測定方法」に基づいて実測する ${ }^{\text {注4) }}$ 。この方法では，暖 房を行ったときの室温とそのときの外乱及び暖房出力の 測定結果から熱損失係数を求めることが基本となってい $3^{102,11)}$ 。したがって，求められた值には，貫流と換気に よる損失熱量が含まれているので，今回は，後述する方 法で換気による熱損失分を除いて，設計図書より求めた 值と比較する。

湘定は，当初，室内発熱に電気温風ヒーターを用いて 8棟全部同時に行う計画であったが，いくつかの住戸で電 気容量が不十分だったため，筷接住戸の電源も利用でき るように，2回に分けて行った。ただし，No.1の住戸のみ 2回とも測定し，その結果を比較することとした。1回目 の同時測定の対象は, No.1,2,3,4,5の5棟，2回目は，No.1, 6,7,8の4棟である。いずれの住戸も竣工直後で室内に家

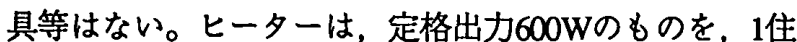
戸につき9台使用した。設置箇所は，各居室と台所，玄関 ホールなどである。また，建物内の室温が一様になるよ うに，すべてのドアを開け，ファンとフレキシブルダク 卜を用いて屋内の空気を攪䢁した。図4に，対象住宅の平 面図と，ヒーターやフレキシブルダクトの設置状況など の一例を示す。なお，各住戸とも，北面を除くガラス面 の外気側にアルミ箔で被覆されたシート(厚さ約 $2 \mathrm{~mm}$ )を 設置し，日射を遮蔽した。ただし，シートはガラス面に は密着させず，風が通るように設置した。

測定は，ファンの運転開始と同時に開始し，暖房停止 後の室温が十分減衰したところで終了するものとした。

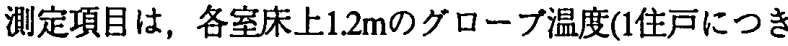
6点), 外気温, 水平面全天日射量, 各方向の相当外気温 (SAT計による)など，総計75点で，道路脇の計湘車の中に
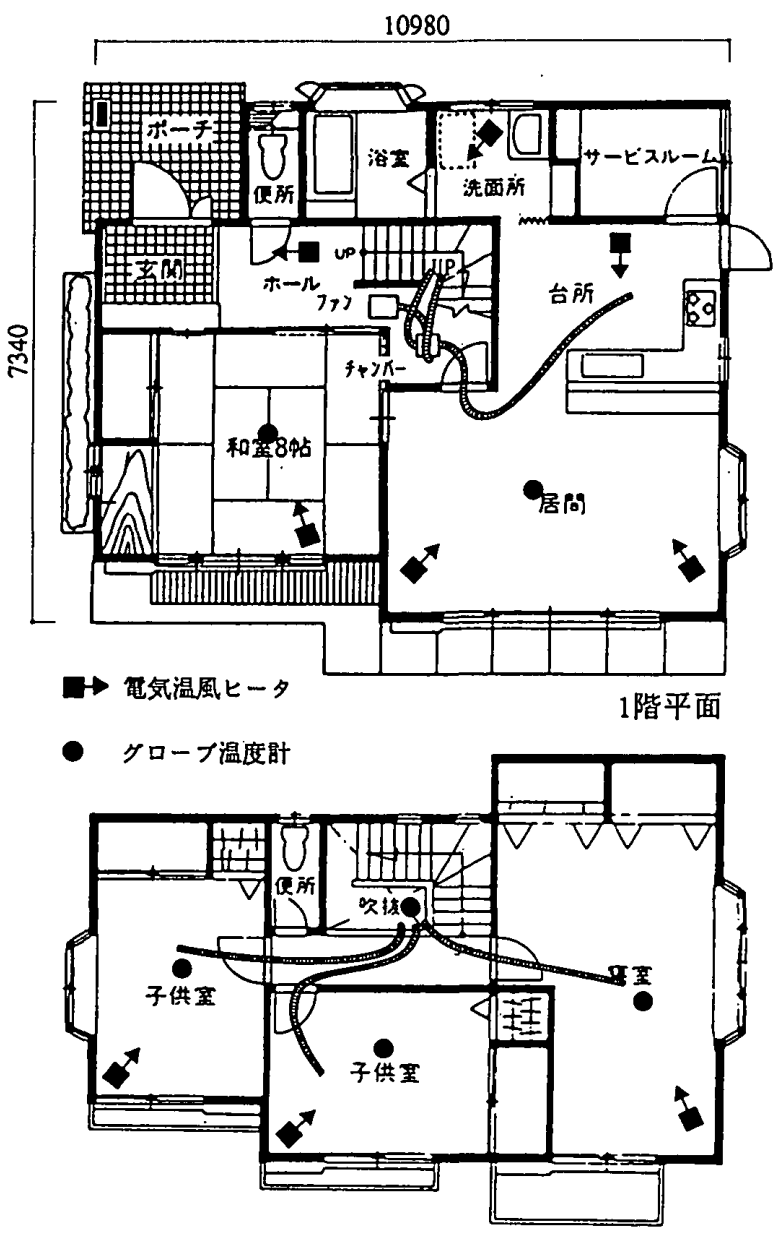

2階平面

図4 対象住宅の平面図とヒータ等の設置状況の一例

置いた多点記録計とマイクロコンピューターを用いて10 分おきに自動収録した。温度の測定には03申CC熱電対， 日射量の測定には太陽電池式日射計を用いた。ヒーター の電力消費量は, 各棟に設置されている積算電力計の值 を2時間おきに読み取った。また，換気による熱損失の推 定のため，同一褡地内の地上8mの風向風速と，一住戸 (No.3)を対象とした各壁面の風圧も測定した。風向風速の 測定には風杯型風向風速計，風王の測定には風圧板と精 密微差圧計を用いた。SAT計や風向風速計などの設置場 所は，図1に示した通りである。表4に，以上の測定項目 をまとめて示す。

\section{2 室内グローブ温度の測定結果}

図5に，1回目の測定から，No.5の住戸における各室グ ローブ温度の測定結果を示す。この期間，天候は雨とき どき悬りで，外気温は3 $8^{\circ} \mathrm{C}$ 範囲で比較的安定してお ク，SAT温度も，変動の大きかった南側で日中最大 $17^{\circ} \mathrm{C}$ 程度と，日射量が少なかったことを示している。各室の グローブ温度は，いずれも，午後9時に暖房が開始される と，その直後は急激に上昇するが，徐々に緩やかにな

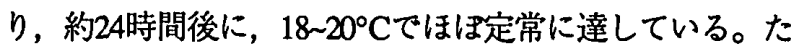
だし，その後は，外気温が下がったため，暖房している 
表4 測定項目

\begin{tabular}{|c|c|c|}
\hline 測定項目 & 测定機器 & 則定期間 \\
\hline 量 & $\begin{array}{c}\text { 太陽霍池式 } \\
\text { 日射斯 }\end{array}$ & \multirow{4}{*}{$\begin{array}{c}\text { 平成2年4月 } \\
\text { 14日 17日 } \\
\text { (住戸 } \\
\text { No.1,2,3,4,5) }\end{array}$} \\
\hline 外気温 & C-C熟電対 & \\
\hline 各方位の相当外気温 & SAT狷 & \\
\hline 各室のグ ロープ 温度 & $y^{\prime}$ घ- $7^{\prime}$ 球 & \\
\hline と-乡の電力消費量 & 積算電力斯 & \multirow{3}{*}{$\begin{array}{c}\text { 平成2年4月 } \\
\text { 17日 19日 } \\
\text { (住戸 } \\
\text { No.1,6,7,8) }\end{array}$} \\
\hline 外部風向風速 & $\begin{array}{c}\text { 風杯型風向 } \\
\text { 風速計 }\end{array}$ & \\
\hline 外壁面風在 & $\begin{array}{c}\text { 風圧板と微 } \\
\text { 差圧計 }\end{array}$ & \\
\hline
\end{tabular}

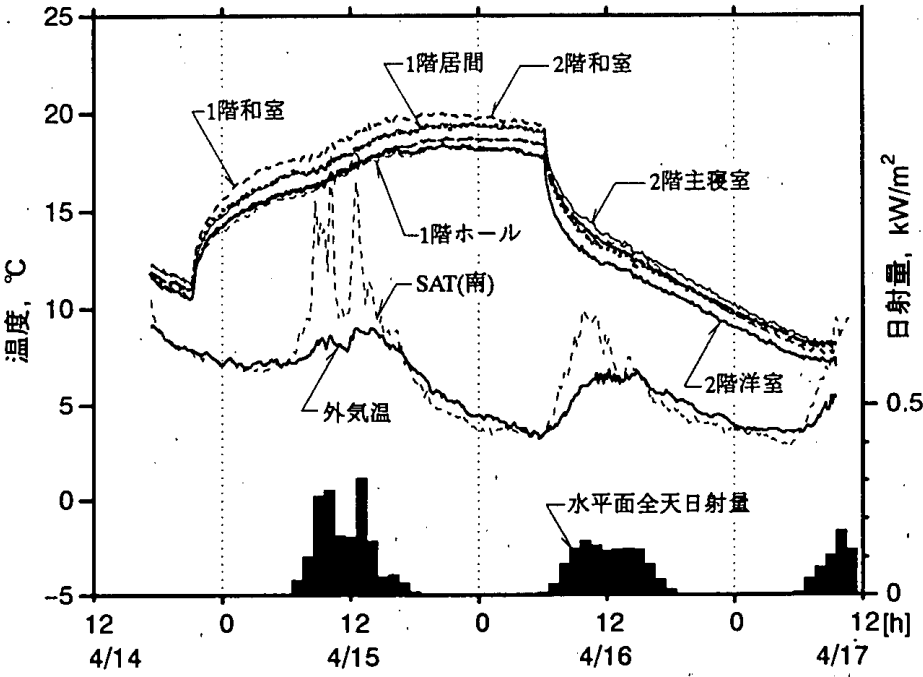

図5 No.5の住戸における各室グローブ温度の測定結果

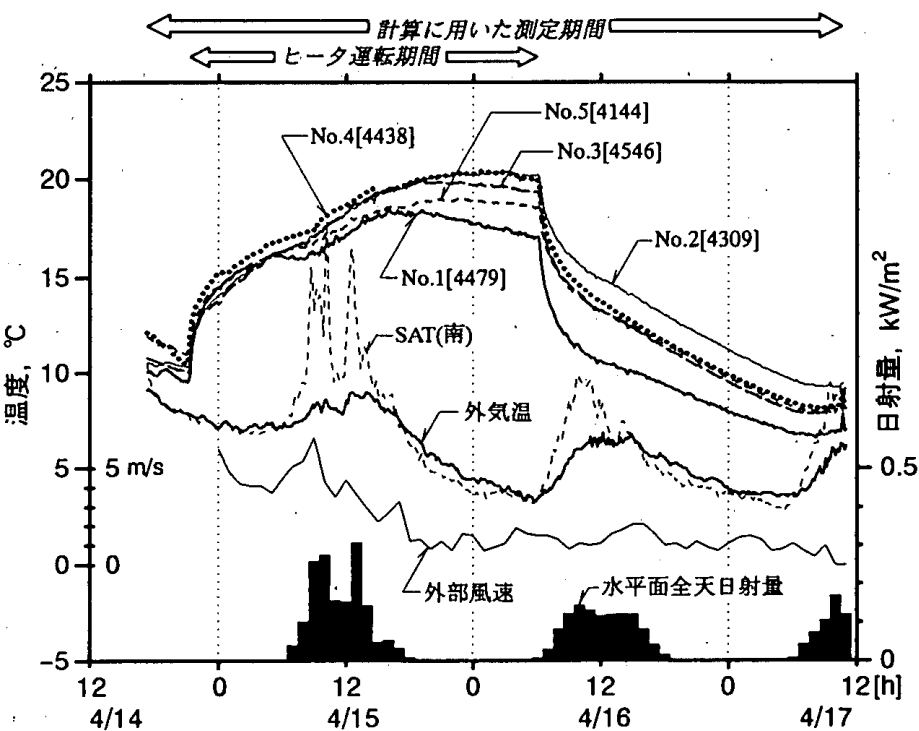

図6 1回目の測定における平均グローブ温度

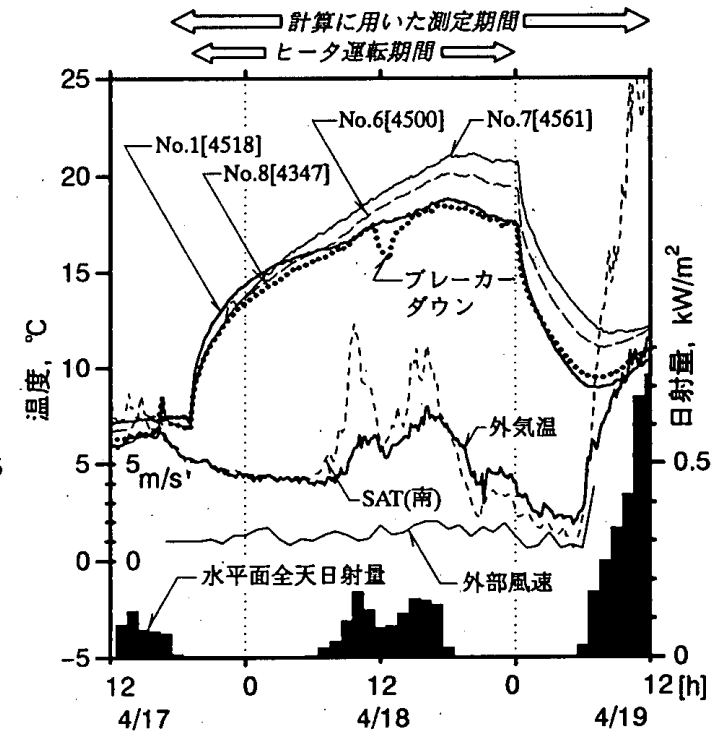

図7 2回目の測定における平均グローブ温度
にもかかわらず室温も若干下がっている。暖房時, 部屋 の中では2階和室の温度が最も高く，1階居間と玄関ホー ルが最も低い。これは, 部屋の容積および位置の違いと 家屋内空気擤拌の不完全さによるものと思われる。しか し，その差は約 $2^{\circ} \mathrm{C}$ と小さ。室温安定時の室内外温度

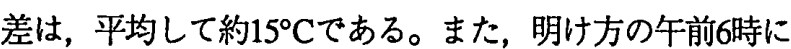
暖房が停止されると，室温は急激に降下し，6時間後で $11.5 \sim 13^{\circ} \mathrm{C}$, 約24時間後の測定終了時で8 -9․․ $\mathrm{C}$ まで下がっ た。いずれにしても，室間の違いは小さかった。

この，暖房時における各室のグローブ温度のばらつき は，他の住戸についても同様で，室内空気の㨽拌によ り，ばらつきの最も大きい住戸(No.2)で，最大 $3.4^{\circ} \mathrm{C}$, 最 も小さい住戸(No.6)で，最大 $1.8^{\circ} \mathrm{C}$ と，小さく抑えられて いることを別途確認した。

以上のグローブ温度の測定結果を, 各室の床面積で加 重平均してその住戸の平均グローブ温度とし，同時測定
した住戸間の比較をしたのが，図6，図7である。それぞ れ，1回目と2回目における測定結果を示している。測定 期間は，1回目が，あしかけ4日間，2回目が3日間で，電 気ヒーターによる暖房時間は，それぞれ，33時間，29時 間である。ヒーターの運転停止時刻は，各住戸の室温(平 均グローブ温度)の変動が定常に近づくのを待って現場で 決定した。

いずれの測定においても，暖房と室温と外乱の関係の 全体的な傾向は，前述した No.5の住戸の場合と同じで あるが, 室温の変化の様子は住戸によって異なり，住戸 ごとの熱性能の違いが明瞭に現れている。1回目の図6に よれば，暖房開始から9時間ほどは住戸間に顕著な違いは みられないが，その後徐々に違いが現れ，暖房停止直前 でみると，室温が最も高くなった No.2,No.4の住戸と， 最も低いNo.1の住戸の差は， $3^{\circ} \mathrm{C} に$ 達している。No.1の住 戸は，暖房停止後の温度降下の程度も最も大きい。2回目 
も同様の傾向がみられるが，図7によれば，暖房停止直前 の温度は, No.7の住戸が最も高く, No.1と No.8の住戸が 最も低い。

図6と図7を比較すると，暖房停止後の気象条件が両者 で全く異なり，1回目のときは外気温の上昇が殆ど室温に 影響を及ほしておらず，室温は䏠日の朝まで降下してい る。一方，2回目の湘定では，暖房を停止した翌日は天候 が良く外気温の上昇が急激であり，それに伴って室温も 上昇している。これらの気象条件の違いが，住戸の熱性 能の推定結果にどのように影響するかについては, No.1 の住戸の結果の比較より明らかにされる。

また, ヒーターの電力消費量は, 各住戸の積算電力計 より求めているが, 各住戸とも同じ温風ヒーターを同じ 数だけ運転したにもかかわらず，電圧降下の違いなどに よりばらつきがみられ，単位時間あたりの熱量換算で, $4144 \mathrm{kcal} / \mathrm{h}$ (No.5) $4561 \mathrm{kcal} / \mathrm{h}$ (No.7)の範囲に分布した。

\section{3 熱損失係数の算定結果}

以上の测定結果に基づいて算出した各住戸の熱的特性 值を表らに示す。これらの值の算出にあたっては，室内の 発熱として，空気擋拌用ファンやモニター用温度記録計 などからの発熱はヒータの出力の4\%以下と小さかったた め，温風ヒータによる発熱のみを採用した。なお，1回目 の測定では，北面SAT温度が欠測したため，計算に用い たSAT温度は5点であった。

1回目の測定結果では，休面積あたりの熱損失係数 $1.74 \sim 2.55 \mathrm{kcal} / \mathrm{m}^{2} \mathrm{~h}^{\circ} \mathrm{C}$, 熱容量 $5031 \sim 5488 \mathrm{kcal} /{ }^{\circ} \mathrm{C}$, 室温変動 率0.041 0.0651/hであるのに対して，2回目の結果では，熱 損失係数 $2.30 \sim 3.08 \mathrm{kcal} / \mathrm{m}^{2} \mathrm{~h}^{\circ} \mathrm{C}$, 熱容量 $2662 \sim 3245 \mathrm{kcal} /{ }^{\circ} \mathrm{C}$, 室温変動率0.092 0.1481/hである。すなわち，2回目に測定 した住戸の方が1回目に測定した住戸に比べて，熱損失係 数と室温変動率の值は大きく，熱容量は小さく計算され た。いずれの測定でも，熱損失係数は，2回測定したNo.1 の住戸が最も大きかったが，その，No.1の住戸の結果に ついてみても，2回目は1回目に対して，熱損失係数では 21\%大きく，熱容量では47\%小さくなっている。したがっ
て，何らかの理由で，2回目の方が熱損失係数は大きめ に，熱容量は小さめに測定されたものとみてよい。換気 による熱損失は，風速が異なっていれば影響するが，2回 目の方が風速は小さく，熱損失に対する影響は逆に現れ ている。

この測定結果の違いについては，先に述べたように， 1回目と2回目の測定では，気象条件が異なるから，その 影響が最も大きな原因として考えられるが，今回の場合 は，暖房停止後の室温と外気温の関係の違いも大きいよ うに思われる。すなわち，1回目の測定では，外気温の上 昇時に暖房を停止したのに対して，2回目の測定では，外 気温の下降時に暖房を停止しており，この結果，暖房停 止後の室温降下は1回目の方が2回目よりも䌅やかになっ た。1回目より2回目の方が大きいという室温変動率の推 定結果は, この室温降下の違いによるものと推察され る。

このほか1回目の測定と2回目の測定では，(1)暖房時間 の長さ，(2)暖房停止後の時間の長さ，の2点が異なって いる。また，今回は，測定期間の制約から，1回目，2回 目とも，暖房開始以前の時間を多くとることができな かったが，この時間のとり方も，2回の湘定では異なって いる。今後，以上の上うな条件の違いに着目した測定と 検討が必要であろう注)。

\section{5. 換気による熱損失を除いた熱損失係数の推定}

実測結果から求めた熱損失係数には換気による熱損失 分が含まれている。そこで，気密性能の実測結果(換気扇 にシールをしない状態)を用いて毎時の換気量を算出し， 期間平均の換気量から室内外温度差 $1^{\circ} \mathrm{C}$ のきの損失熱量 を求めて，それを先に測定した熱損失係数から差し引 き，換気による熱損失分を除いた熱損失係数を推定し た。

換気計算は，建物全体を1室とみなして行った。知間 は，各階各方位の外壁上下 2 ヶ所，および天井面と床面
表5 各住戸における熱損失係数の算出結果

\begin{tabular}{|c|c|c|c|c|c|c|c|}
\hline & $\begin{array}{l}\text { 住戸 } \\
\text { No. }\end{array}$ & $\begin{array}{c}\text { 計算に用いた } \\
\text { データの数 }\end{array}$ & $\begin{array}{c}\text { 七-9加熱量 } \\
{[\mathrm{kcal} / \mathrm{h}]}\end{array}$ & $\begin{array}{c}\text { 室温㥋動率 } \\
{[1 / \mathrm{h}]}\end{array}$ & $\begin{array}{c}\text { 鰵損失係数KA } \\
{\left[\mathrm{kcal} / \mathrm{h}^{2} \mathrm{C}\right]}\end{array}$ & $\begin{array}{c}\text { 床面積当たり } \mathrm{KA} \\
{\left[\mathrm{kcal} / \mathrm{m}^{2} \mathrm{~h} C\right]}\end{array}$ & 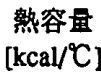 \\
\hline \multirow{5}{*}{$\begin{array}{l}1 \\
\text { 回 } \\
\text { 目 }\end{array}$} & 1 & \multirow{5}{*}{\begin{tabular}{ll} 
外気温 & 1 点 \\
SAT温度 & 5 点 \\
室温 1 点 \\
\multicolumn{2}{c}{ (400個/点) }
\end{tabular}} & 4479 & 0.065 & 327 & 2.55 & 5030.8 \\
\hline & 2 & & 4309 & 0.041 & 225 & 1.74 & 5487.8 \\
\hline & 3 & & 4546 & 0.053 & 268 & 2.08 & 5056.6 \\
\hline & 4 & & 4438 & 0.047 & 252 & 1.95 & 5361.7 \\
\hline & 5 & & 4144 & 0.047 & 251 & 1.93 & 5340.4 \\
\hline \multirow{4}{*}{$\begin{array}{l}2 \\
\text { 回 } \\
\text { 目 }\end{array}$} & 1 & \multirow{4}{*}{$\begin{array}{ll}\text { 外気温 } & 1 \text { 点 } \\
\text { SAT温度 } & 6 \text { 点 } \\
\text { 室温 1 } 1 \text { 点 } \\
\text { (250個/点) }\end{array}$} & 4518 & 0.148 & 394 & 3.08 & 2662.2 \\
\hline & 6 & & 4500 & 0.106 & 344 & 2.75 & 3245.3 \\
\hline & 7 & & 4561 & 0.092 & 290 & 2.30 & 3152.2 \\
\hline & 8 & & 4347 & 0.112 & 346 & 2.66 & 3089.3 \\
\hline
\end{tabular}

表6 各壁面の室内外圧力差係数

\begin{tabular}{c|c|c}
\hline \multirow{2}{*}{} & \multicolumn{2}{|c}{ 室内外圧力差係数 } \\
\cline { 2 - 3 } & 1 回目 & 2回目 \\
\hline 北 & 0.48 & 0.35 \\
\hline 東 & -0.20 & -0.25 \\
\hline 南 & -0.21 & -0.25 \\
\hline 西 & 0.30 & -0.31 \\
\hline 天井 & 0.07 & 0.07 \\
\hline 床下 & -0.18 & -0.19 \\
\hline
\end{tabular}


1ヶ所づつの開口に置き換え，その面積は，気密性能の実 湘結果を基に外壁面積に応じて設定した。なお，実測結 果によれば，換気扇の隙間が相対的に大きな割合を占め る住戸もあったが，今回は，隙間の設定の際に換気扇は 考慮しながった。換気量は，ニュートンラフソン法を用 いた収束計算 ${ }^{11)}$ にり室内圧と各開口の流量を算出し， 1時間ごとに求める。計算に使用するデー夕は，室温，外 気温，外部風速の1時間ごとの実測值である。風向につい ては，この期間中の主風向は北であったことから，北向 き一定とした。また，No.3の住戸の風王板における室内 圧基準の風王の測定值より，表6に示すような各壁面ごと の室内外の圧力差係数を求め, これを風圧係数とした。 No.3の住戸は，而隣が他の住戸にはさまれており8棟の両 端の住戸の風圧係数とは異なるが，今回は，それぞれの 測定期間ごとにすべての住戸で風圧係数は同一とした。

表7に，湘定期間中における各住戸の平均換気量とそれ による熱損失を除いた熱損失係数の算出結果を示す。

換気量は, 当然のことながら気密性能の測定結果に対 応している。最も気密性能が低いNo.1の住戸の換気量 は, 1 回目 $383 \mathrm{~m}^{3} \mathrm{~h}$, 2回目 $337 \mathrm{~m}^{3} / \mathrm{h}$ と, 8棟の中では最も大 きく推定され，これは, 最も気密性能が高いNo.2の住戸 の換気量の約7倍の值となっている。

換気による熱損失を除いた床面積当たりの熱損失係数 は，1.62 2.58kcal/ $/ \mathrm{m}^{2} \mathrm{~h}^{\circ} \mathrm{C}$ と計算された。全熱損失俰数に占 める換気負荷の割合は，No.1の住戸が1回目 $34 \% ， 2$ 回目 $25 \%$ と最も大きく，No.2とNo.6の住戸が $6 \%$ と最も小さ かった。その他の住戸の換気負荷の大きさは，8 14\%に 分布している。熱損失量の低減における気密性能の重要 性が示唆されていると言える。

図8は，8住戸について，設計図書から得られる熱損失 係数の概算值と今回測定した熱損失係数を比較したもの である。今回测定したものについては，換気の分を含め たものと換気の分を除いたものの両方を示した。No.2の 住戸が設計值と測定值でほほ一致している他は，両者は 上下にばらついている。すなわち，1回目の測定住戸は設 計値より測定值の方が小さく，2回目の測定住戸は，No.1 を除いて，設計值より測定值の方が大きく見積もられて いることが判る。とくに，No.4とNo.7の住戸の違いが大 きく，換気による熱損失を除いた值では，No.4の住戸は 設計值より31\%小さく，No.7の住戸は設計值より39\%大き く湘定される結果となった。しかし，これらを除くと， 対象住戸の熱損失係数は，概ね，設計值の $\pm 15 \% の$ 範囲に 測定されていた。

\section{6. 結語}

仙台市北部の新興団地に並び建つ8戸の戸建住宅を対象 として，爇損失係数に関する現場測定を行った。結果を
表7 換気熱損失分を除いた熱損失係数

\begin{tabular}{c|c|c|c|c}
\hline & $\begin{array}{c}\text { 住戸 } \\
\text { No. }\end{array}$ & $\begin{array}{c}\text { 床面積当たり } \\
\mathrm{KA}\left[\mathrm{kcal} / \mathrm{m}^{2} \mathrm{~h} \mathrm{C}\right]\end{array}$ & $\begin{array}{c}\text { 換気量 } \\
{\left[\mathrm{m}^{3} / \mathrm{h}\right]}\end{array}$ & $\begin{array}{c}\text { 換気分を除いた } \\
\mathrm{KA}\left[\mathrm{kcal} / \mathrm{m}^{2} \mathrm{~h} \mathrm{C}\right]\end{array}$ \\
\hline \multirow{4}{*}{$\begin{array}{c}1 \\
\text { 回 }\end{array}$} & 1 & 2.55 & 383 & 1.69 \\
\cline { 2 - 5 } & 2 & 1.74 & 56 & 1.62 \\
\cline { 2 - 5 } 目 & 3 & 2.08 & 133 & 1.78 \\
\cline { 2 - 5 } & 4 & 1.95 & 104 & 1.72 \\
\hline \multirow{2}{*}{2} & 5 & 1.93 & 104 & 1.70 \\
\hline 回 & 1 & 3.08 & 337 & 2.32 \\
\hline 目 & 6 & 2.75 & 73 & 2.58 \\
\hline & 7 & 2.30 & 121 & 2.03 \\
\hline & 8 & 2.66 & 90 & 2.46 \\
\hline
\end{tabular}

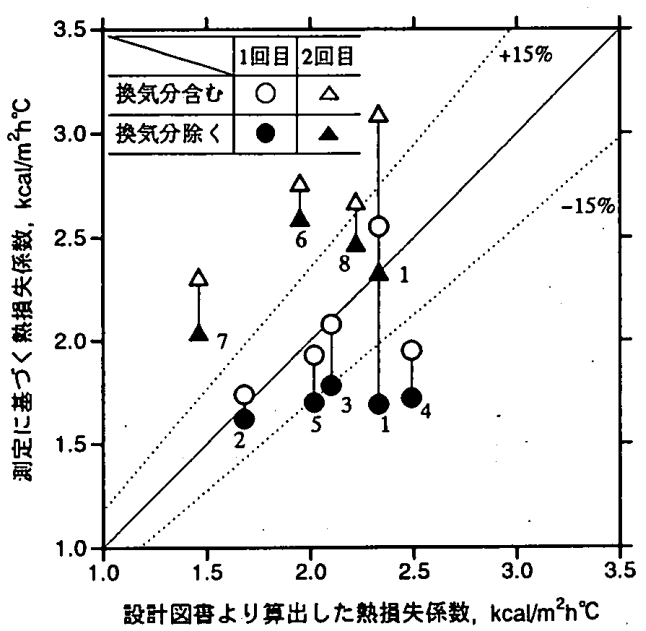

図8 測定值と設計值との比較

まとめると以下の通りである。

(1)住宅の気滵性能は，延床面積当たりの相当開口面積が $3.0 \sim 16.4 \mathrm{~cm}^{2} / \mathrm{m}^{2}$ に分布した。気密性能のグレードとして は，北海道を除くわが国の戸建住宅のほほ平均的なグ レードに位置していた。相当開口面積の最も大きな住 戸は在来木造軸組工法であり，住宅の気密性能には， 建物の構造が大きく影響していることが推定された。

(2) 熱損失係数の測定は，数戸づつ2回に分けて同時に行っ たが，その結果，1回目が1.74 -2.55 kcal/m² $\mathrm{h}^{\circ} \mathrm{C}$ ，2回目が 230 - 3.08 $\mathrm{kcal} / \mathrm{m}^{2} \mathrm{~h}^{\circ} \mathrm{C}$ と，2回目に測定した住戸の方が1回 目に測定した住戸より大きく測定される傾向がみられ た。2回測定した住戸の熱損失係数についてみても， 2回目の測定結果の方が1回目より21\%大きかった。こ れらについては，気象条件の違いに加えて，暖房停止 時刻の選び方や暖房時間の長さなど，測定条件の違い が原因として推察された。

(3)気密性能の実測結果に基づき換気量を計算し，換気に よる熱損失分を除いた熱損失俰数を推定した。全熱損 失係数に占める換気負荷の割合は，最も大きな住戸で 約 $30 \%$ ，最も小ざい住戸で6\%，その他は8 14\%に分布 した。この換気分を除いた熱損失係数を，設計図書よ 
り見積もった貫流分だけの熱損失係数の概算值と比較 したところ，8棟のうち5棟が設計值の $\pm 15 \% の$ 範囲に 入っていた。

\section{あとがき}

本研究を行うにあたっては，(株)ミサワホーム絵合研究所にご勐 力、こ援助を頂いた。湘定にあたっては，宮城工業高等専門学校助 教授 内海康雄氏，東北大学技官 佐々木耕一氏，大成建設(株)豊原 籍之氏(当時東北大学大学院生)らに多大なるこ協力を頂いた。また， 本論文をまとめるにあたっては，(株)日本設計 由良仁志氏(当時東北 大学大学院生), 東北大学大学院生 長谷川兼一君に多くの労を煩わ せた。ここに記して深甚なる譈意を表する次第です。

注

1) 本論文は，既に発表している文献(1)に対して，さらに考察を加え， 修正，加筆したものである。

2）設計图茟に基づく熱提失俰数 $K A$ は，住宅内をすべて居室とみ なして，次式て算出した。ここでは，換気による熱損失が不明な ため，貫流熱損失のみを対象としている。

$$
K A=\sum \frac{A_{j} K_{J} H_{j}}{S}
$$

ここに, $A_{j}$ は， $j$ 部位の外気，床哀または外気に通しる小屋裹も しくは天井稁に面する面皘 $\left(\mathrm{m}^{2}\right), \quad K_{j}$ は， $j$ 部位の熱貫流率(kcal

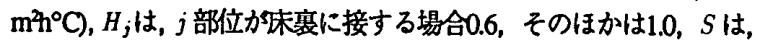
本面皘の合㹁 $\left(\mathrm{m}^{2}\right)$ である。熱貫流率の算出にあたっては，内外表 面の釉合熱伝達率は，それぞれ，8.0，20.0(いずれも $\left.\mathrm{kcal} / \mathrm{m}^{2} \AA^{\circ} \mathrm{C}\right)$ と した。

3) 気密性能の测定法には，室内を負圧にする減圧法もあるが，既往 の研究流によれは，減圧法の結果は加圧法に比へて漏気量が減少す る傾向にあり，その差は約10\%程度といわれている。本論文5章で は, 気密性能の結果に基ついて換気量を推定するが，その場合に は，换気計算に関わ乃諸要素の测定精度から考えて，加圧法と減 圧法の違いの影響はそれはど大きくはないと思われる。

4) 日本工業規格(案「現場に扔了部屋の暖房用給熱損失係数剆定方 法」はもともと，住宅内の一室，もしくは同一住宅内の数室を 同時に暖房する場合の部屋の暖房用給熱損失保数を，現場におい て測定する方法を规定したものであるが，本実测は，これを住宅 全体を一室とみなした場合に適用したものである。以下にここの 方法に损け万熱損失保数の求め方の概要を示す。詳細は，文献了), 10)，11)を参照されたい。

いま，熱損失保数を求めようとする空間において，ある時刻以 後，急に $H \mathrm{kcalh}$ の暖房を継続したときこれによる室温 $\theta_{H}(t)$ は， $\theta_{H}(t)=B_{H 1}+B_{H_{2}}\left(1-e^{-\lambda_{2} t}\right)$

$$
+B_{H 3}\left(1-e^{-\lambda_{3} t}\right)+\ldots+B_{H \infty}\left(1-e^{-\lambda_{\infty} t}\right) \text { (4.1) }
$$

という無限多項式になる。ここでは，これを次のように近似する。 $\theta_{H}(t)=B_{H_{1}}+B_{H 2}\left(1-e^{-\lambda t}\right)$

一方，外気温や日射などの外乱がステッブ状に変動したときの 応答関数を，暖房の場合と同様に，

$$
\phi(t)=1-e^{-\lambda t}
$$

と近似すると，この式によって，各方位の外乱の影響で生じる室 温をそれぞれ表現できることになる。実際の室温は，暖房による 室温と各外乱による室温の和と考えられるから，これと観測され た室温との間に最小自乘法を適用すれは，未知数 $\lambda, B_{H_{1}}, B_{H_{2}}$ ’s $^{5}$

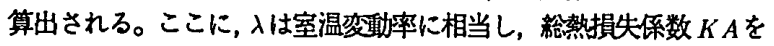
対象空間の熱容量で除した值である。

以上が求まれは， $t \rightarrow \infty$ の定常状態ては，

$$
\theta_{H}(t)=B_{H 1}+B_{H 2}
$$

となるから，暖房用総熱損失俰数の定義(外気温が $0^{\circ} \mathrm{C}$ とき，建

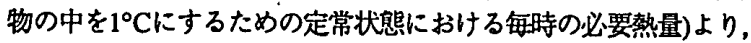
$K A$ は,

$$
K A=\frac{H}{B_{H 1}+B_{H 2}}
$$

となる。これを延床面糟て割れば，その值は，住宅の省エネルギー 基準でいうところの熟損失保数に相当する。

5) 付表 $1 に$ ，暖房停止後の時間のとり方について，1回目の测定のと きの時間(デー夕個数)を2回目の測定と同しにして計算した結果を 示す。1回目に测定した5つの住戸とも，熱損失保数なとの熱的特 性值か，先に示した值よりも2回目に測定した住戸のそれに近い值 に計算されている。2回测定したNo.1の住戸についてみれは，熱損 失保数は概ね一致している。しかし，熟容量は，なお25\%小さい。 いずれにしても，暖房停止後のア゙ータ個数のとり方が結果に大き

\begin{tabular}{|c|c|c|c|c|c|}
\hline & $\begin{array}{l}\text { 住戸 } \\
\text { No. }\end{array}$ & $\begin{array}{c}\text { 室温变動率 } \\
{[1 \mathrm{M}]}\end{array}$ & $\begin{array}{c}\text { 熟損失係数KA } \\
{\left[\mathrm{kcal} / \mathrm{h}^{2} \mathrm{C}\right]}\end{array}$ & $\begin{array}{c}\text { 床面積当たり KA } \\
{[\mathrm{kcal} / \mathrm{m} 2 \mathrm{~h} \complement]}\end{array}$ & $\begin{array}{c}\text { 熟容是 } \\
\text { [kcal/C] }\end{array}$ \\
\hline \multirow{5}{*}{$\begin{array}{l}1 \\
\text { 回 } \\
\text { 目 }\end{array}$} & 1 & 0.106 & 379 & 2.96 & 3575.5 \\
\hline & 2 & 0.053 & 256 & 1.98 & 4830.2 \\
\hline & 3 & 0.077 & 313 & 2.43 & 4064.9 \\
\hline & 4 & 0.059 & 281 & 2.18 & 4762.7 \\
\hline & 5 & 0.065 & 295 & 2.27 & 4538.5 \\
\hline \multirow{4}{*}{$\begin{array}{l}2 \\
\text { 回 } \\
\text { 目 }\end{array}$} & 1 & 0.148 & 394 & 3.08 & 2662.2 \\
\hline & 6 & 0.106 & 344 & 2.75 & 3245.3 \\
\hline & 7 & 0.092 & 290 & 2.30 & 3152.2 \\
\hline & 8 & 0.112 & 346 & 2.66 & 3089.3 \\
\hline
\end{tabular}
〈影瑤していることが判る。その他の時刻の選じ方とア゙ー夕個数 のとり方の影那については，今回の測定からは検討できす，今後 の課題である。

付表1 各住戸における熱損失保数の算出結果

\section{参考文献}

1) 石川善美, 長友宗重, 吉野 博, 松本真一，豊原範之：複数の住 戸を対象とした暖房用熱提失保数の同時测定, 日本建築学会大会 学術講演梗概集, pp.755 756, 1990.10.

2) 日本工業规格(案): 現場における部屋の暧房用熱提失保数测定方 法およU付属费「現場における部屋の暖房用粉熱提失俰数の計算 方法」拈よび解説(案), 1983.6 .

3）長谷川房雄，柎建一，吉野 博，石川善美，松本 博：パッシ

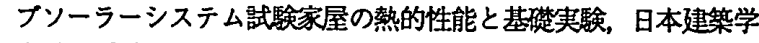
会計画系論文報告集，第361号，pp.21 30, 1986.3.

4）長谷川房雄，柎建一，吉野 博，石川荃美，松本 博：パッシ プンーラーシステム試験家屋を用いた蓄熱床方式に関する実験的 研究。日本建築学会計画系論文報告集，第366号，pp.33-41, 1986.8.

5）通産省·建設省告示第1号：住宅に保わるエネルギーの使用の合理 化に関する建筑主の判断の基準, 1980.2 .

の) 建設省住宅局住宅生産課監修：新省エネルギー基準と指針，(財) 住宅·建築省エネルギー機構, 1992.4 .

7) 村上周三, 吉野 博: 住宅の気密性能に関す万研究，日本建築学 会論文報告集，第325号，pp.104-115, 1983.3.

8）金 埈營，長友宗重，吉野 博，赤林伸一: 気密性能の測定に扔 ける加法法と減圧法の比較，日本建筑学会大会学術講演梗概集， pp.615-616, 1992.8.

9）吉野 博：住宅の気窑性能とその基準に関する動向調查，日本建 筑学会大会学術講演梗概集, pp.561 562, 1990.10.

10）松尾 陽：測定に基づく室温予测およひ暖房性能の評価法につい $\tau$, 日本建築学会大会学術講演梗概集, pp.337 338, 1976.10.

11)松尾 陽, 斎藤平藏：現場測定にもとづく住宅熱特性の推定, 日 本建築学会理境工学論文集, 第3号, pp.13 18, 1981.4 .

12) 長谷川房雄，石川善美，水口広隆：電算機を用いた換気計算につ いて -開口の特性がグラフ又は数表で表される場合の取り扱い2, 日本建筑学会大会学術譵演梗概集, pp.245 -246, 1975.10.

（1994年11月10日原稿受理，1995年 4 月20日採用決定） 